\title{
Agro-environmental scheme for segetal plant conservation in Wallonia (Belgium): an assessment in conventional and organic fields
}

\author{
Cyril Lemoine ${ }^{(1)}$, Emmanuël Sérusiaux ${ }^{(2)}$, Grégory Mahy ${ }^{(3)}$, Julien Piqueray ${ }^{(1)}$ \\ (1) Natagriwal ASBL, site de Gembloux. Passage des Déportés, 2. BE-5030 Gembloux (Belgium). \\ E-mail: jpiqueray@natagriwal.be \\ (2) University of Liège. Evolution and Conservation Biology. Sart Tilman B22. BE-4000 Liège (Belgium). \\ (3) University of Liège - Gembloux Agro-Bio Tech. Biodiversity and Landscape Unit. Passage des Déportés, 2. \\ BE-5030 Gembloux (Belgium).
}

Received 23 March 2017, accepted 8 December 2017, available online 12 January 2018.

This article is distributed under the terms and conditions of the CC-BY License (http://creativecommons.org/licenses/by/4.0)

Description of the subject. Segetal plant species are highly threatened in arable land. They are an integral part of agricultural history and biodiversity in Western Europe. In Wallonia (southern Belgium), an agro-environmental scheme (AES) has been adopted for their conservation. It consists of strips on a field margin, with at least $60 \%$ cereals in crop rotation, and proscribes spraying and fertilisation.

Objectives. This paper assessed the impact of an AES on segetal species conservation.

Method. In eight organic fields and six conventional fields, a vegetation survey was performed on an AES strip and on a control margin of each field. Evenness, richness, cover and species composition for both total and segetal species were compared between AES strips and their corresponding control margins. Also, a cover of pernicious weeds was considered to be a factor in the rejection of AES by farmers.

Results. In conventional agriculture, species richness (total and segetal) and cover (total and segetal) were higher in the AES than in the respective control; however, pernicious weed cover was also enhanced. In organic fields, total species richness was higher and pernicious weed cover was lower in the AES than in the respective control. Total evenness was higher in organic than in conventional fields, due to the co-dominance of several species. Under the AES, species composition and abundance remained different between conventional and organic fields. In all cases, rare species were hardly found in our survey.

Conclusions. AES promote plant diversity in both organic and conventional fields. Sowing AES strips with uncleaned seeds from well-preserved fields, or species introduction, are recommended to enhance rare species recovery.

Keywords. Segetal plants, environmental policies, biodiversity conservation, organic agriculture, conventional farming, Belgium.

Mesure agro-environnementale en faveur des plantes messicoles en Wallonie (Belgique) : évaluation dans des champs d'agriculture conventionnelle et biologique

Description du sujet. Les plantes messicoles font partie intégrante de la biodiversité et de l'histoire de l'agriculture et sont fortement menacées en Europe de l'Ouest. En Wallonie (Sud de la Belgique), une mesure agro-environnementale (MAE) est dédiée à leur conservation. Elle consiste à cultiver des bordures de champs sans engrais ni pesticide et en incluant au moins $60 \%$ de céréales dans la rotation.

Objectifs. Cette étude évalue l'impact de cette MAE sur la conservation des plantes messicoles.

Méthode. Dans huit champs d'agriculture biologique et six champs conventionnels, des relevés de végétation ont été réalisés dans les bandes MAE et dans une bordure témoin par champ. Les diversités, compositions et abondances totales et des taxons messicoles ont été comparés entre les bandes MAE et leurs témoins respectifs. L'abondance des plantes nuisibles aux cultures a aussi été prise en compte en tant que facteur de rejet des MAE par les agriculteurs.

Résultats. En agriculture conventionnelle, la richesse en espèces (totale et messicoles) et l'abondance (totale et de messicoles) étaient plus grandes dans les MAE que dans les témoins. Cependant, l'abondance des plantes nuisibles était elle aussi plus élevée. Dans les champs biologiques, la richesse spécifique totale était plus élevée, tandis que l'abondance des nuisibles était 
plus faible dans les MAE que dans les témoins. L'équitabilité totale des champs biologiques était plus élevée que celle des champs conventionnels du fait de la co-dominance de plusieurs espèces. Les végétations et compositions en espèces dans les MAE restaient différentes entre l'agriculture biologique et conventionnelle. Dans tous les cas, les espèces rares n'étaient que peu présentes dans nos relevés.

Conclusions. Les MAE favorisent la diversité végétale tant dans les champs biologiques que conventionnels. L'ensemencement des bordures MAE avec des semences non triées prélevées sur des champs riches en espèces ou le semis direct d'espèces menacées sont recommandés pour favoriser le retour de ces espèces.

Mots-clés. Plantes messicoles, politique de l'environnement, conservation de la diversité biologique, agriculture biologique, agriculture conventionnelle, Belgique.

\section{INTRODUCTION}

Since the 1950s, agriculture has intensified drastically, which has led to a significant biodiversity decline in arable lands (Stoate et al., 2001). Fauna and flora have become severely impoverished in agroecosystems, which in turn has affected functions and services provided by these ecosystems (Tscharntke et al., 2005; Sutcliffe et al., 2015). Among the flora associated with arable lands, segetal plant species are those that grow preferentially in cereal fields, and are therefore considered specialist species of this habitat (RotchésRibalta et al., 2016). Segetal plants are an integral part of European agricultural history. At the onset of the expansion of agriculture from the Middle East and the Mediterranean basin, they were brought with crops hundreds or even thousands of years ago and finally became established in Europe's cropland several centuries ago. Some of them evolved under cropping conditions and have no natural habitats outside of arable fields (Storkey et al., 2012; Albrecht et al., 2016). Segetal plants are therefore vestiges of a cultural legacy, and indicators of traditional land management that is worth preserving. They, however, have suffered a decline during the last century, due to changes in agricultural practices (Storkey et al., 2012). The main causes of the decline have been the increasing use of herbicides and fertilizers, as well as landscape homogenization that has led to a decrease in field margin density, which is seen as the refuge area for segetal plants (Albrecht et al., 2016). Also, deep ploughing (burying of propagules) and efficient seedcleaning processes have exacerbated segetal species decline (Fried et al., 2009; Storkey et al., 2012). Consequently, segetal species are nowadays highly threatened throughout Europe (Storkey et al., 2012).

Arable plants may play an important role in the functioning of agroecosystems, and provide several ecological services. By providing pollen and nectar to insects, they can enhance crop pollination and biological pest control. Some of them also constitute a valuable food resource for farmland birds (Wilson et al., 1999; Marshall et al., 2003; Nicholls \& Altieri, 2004; Haaland et al., 2011; Nicholls \& Altieri, 2013). Some segetal plants (e.g. Centaurea cyanus and Papaver spp.) are known to be good nectar and pollen providers (Hicks et al., 2016); however, weeds are generally considered as a constraint on crops. Some of them may indeed reveal pernicious habits and contribute to severe yield loss. Segetal plant conservation programs should, therefore, pay special attention to not promoting proliferation of such pernicious weeds (Wagner et al., 2017).

Facing environmental degradation, due to agricultural intensification, many countries have adopted options within subsidized agro-environmental schemes (AES) that promote farmland biodiversity (Batáry et al., 2015). In Wallonia (southern Belgium), one of these schemes is dedicated to threatened and declining segetal species (MC8: 'Strips adapted for segetal plant conservation'). It is targeted at fields presenting a high potential for segetal plant conservation. The selection of these fields relies on expert judgment, based on recent observations of threatened species in the close vicinity (ca. $500 \mathrm{~m}$ radius). The contract is established by a farm advisor who supports farmers during contract execution (see Piqueray et al., 2016 for details on the role of Natagriwal advisors in the Walloon AES). The AES consists of a typically 12-m-wide strip at the field margin, and targets spontaneous segetal plants. Cereals have to be cropped in at least three years over the fiveyear contract. Spraying and fertilizing are prohibited. Harvesting must be implemented when the grain is ripe (no immature cereal cropping) to allow the completion of segetal plant life-cycles, including seed shedding.

The corresponding AES has a cost to society $\left(1,250 € \cdot \mathrm{ha}^{-1} \cdot\right.$ year $^{-1}$ at study time, increased to $1,500 €$. ha $^{-1}$.year ${ }^{-1}$ from 2018 [Service public de Wallonie, 2017a]) and, therefore, the achievements must be evaluated. Assessment has to be done with regard to the objectives (here, segetal plant conservation), and compared to the usual farming practices. Among these practices, organic agriculture is known to have beneficial effects on arable weeds (Hyvönen et al., 2003; Bengtsson et al., 2005). Organic agriculture is also subsidized, but at a lower rate than AES in Wallonia (ca. $400 € \cdot$ ha $^{-1} \cdot$ year $^{-1}$ for cereals, not cumulative to the AES [Service public de Wallonie, 2017b]). Some of the prescriptions in organic agriculture, including 
the absence of spraying, are similar to those of the AES. Other prescriptions may be different, such as fertilization (forbidden in AES, while organic fertilization is authorized in organic agriculture). There is, therefore, a need to evaluate whether AES prescriptions provide a benefit for arable plants, if organic farming is implemented.

The objectives of the current study were, therefore, to assess the efficiency of AES margins for improvement of plant diversity in general, and for segetal plant conservation in particular. Special attention was paid to threatened and declining species. We also considered the impact of management on the development of pernicious species, as an indicator of farmers' rejection of such AES. The assessment was conducted on both organic and conventional farms, in order to compare effects within and between both farming systems.

\section{METHODOLOGY}

\subsection{Study site}

We selected agricultural crop fields having part of their margin under a segetal plant conservation AES contract. They were selected if one part of their margin was free of the AES, to serve as a control margin. Control margins in each crop field must have the same soil conditions, based on the Digital Soil Map of Wallonia (DSMW) (Bock et al., 2008), and exhibit no evident environmental differences (e.g. shadowing, slope, aspect, etc.) to the AES margin. Finally, the crop field had to be sown with cereal in 2016 (year of the study). Under these restrictive conditions, we were able to find
14 crop fields. Among these fields, 6 were managed conventionally and 8 were organic. AES contracts were initiated from 2007 to 2016 (Table 1). All fields contained silty to gravelly-silty soils, with favorable natural drainage, i.e. drainage class ' $\mathrm{b}$ ' in the DSMW (Bock et al., 2008).

\subsection{Data collection}

In June 2016, at each of the 14 study fields, 10 vegetation plots (size $2.5 \mathrm{~m} \times 2.5 \mathrm{~m}$ ) were surveyed. For each field, 5 plots were located at the AES margin and 5 in the control margin. All plots were located $6 \mathrm{~m}$ from the field edge, and at least $25 \mathrm{~m}$ from a field corner. Higher plants were listed, and the abundance of all species was estimated using the Braun-Blanquet (1932) scale of plant-cover abundance. Mean class values of plant-cover abundance were considered for analysis. Cropped species (i.e. cereals) were not considered in the vegetation survey. The nomenclature follows Lambinon et al. (2004).

\subsection{Data analysis}

We computed seven indices to evaluate the impact of the AES and organic farming on weeds:

- total species richness $\left(\mathrm{S}_{\text {tot }}\right)$;

- total plant cover $\left(\mathrm{Cov}_{\text {tot }}\right.$, sum of individual species cover);

- segetal species richness $\left(\mathrm{S}_{\mathrm{seg}}\right)$;

- total segetal plant cover $\left(\mathrm{Cov}_{\text {seg }}\right.$, sum of individual species cover);

- pernicious species cover $\left(\operatorname{Cov}_{\text {pern }}\right.$, sum of individual species cover);

Table 1. Characteristics of the 14 investigated crop fields - Caractéristiques des 14 champs évalués.

\begin{tabular}{|c|c|c|c|c|}
\hline Field & Agriculture system & Initial year of the AES contract & Culture & Locality \\
\hline b1 & Conventional & 2014 & Wheat & $4^{\circ} 33^{\prime} 28^{\prime \prime} \mathrm{E}, 50^{\circ} 04^{\prime} 23^{\prime \prime} \mathrm{N}$; elev.: $204 \mathrm{~m}$ \\
\hline b2 & Conventional & 2014 & Wheat & $4^{\circ} 33^{\prime} 33^{\prime \prime} \mathrm{E}, 50^{\circ} 04^{\prime} 20^{\prime \prime} \mathrm{N}$; elev.: $210 \mathrm{~m}$ \\
\hline b3 & Conventional & 2014 & Wheat & $4^{\circ} 34^{\prime} 08^{\prime \prime} \mathrm{E}, 50^{\circ} 04^{\prime} 30^{\prime \prime} \mathrm{N}$; elev.: $213 \mathrm{~m}$ \\
\hline b4 & Conventional & 2013 & Wheat & $4^{\circ} 42^{\prime} 32^{\prime \prime} \mathrm{E}, 50^{\circ} 06^{\prime} 47^{\prime \prime} \mathrm{N}$; elev.: $217 \mathrm{~m}$ \\
\hline b5 & Organic & 2009 & Spelt & $4^{\circ} 58^{\prime} 18^{\prime \prime} \mathrm{E}, 50^{\circ} 10^{\prime} 34^{\prime \prime} \mathrm{N}$; elev.: $268 \mathrm{~m}$ \\
\hline b6 & Organic & 2009 & Spelt & $4^{\circ} 59^{\prime} 25^{\prime \prime} \mathrm{E}, 50^{\circ} 11^{\prime} 28^{\prime \prime} \mathrm{N}$; elev.: $196 \mathrm{~m}$ \\
\hline b7 & Organic & 2014 & Barley & $5^{\circ} 08^{\prime} 11^{\prime \prime} \mathrm{E}, 50^{\circ} 15^{\prime} 03^{\prime \prime} \mathrm{N}$; elev.: $313 \mathrm{~m}$ \\
\hline b8 & Organic & 2014 & Wheat & $5^{\circ} 08^{\prime} 37^{\prime \prime} \mathrm{E}, 50^{\circ} 15^{\prime} 06^{\prime \prime} \mathrm{N}$; elev.: $316 \mathrm{~m}$ \\
\hline b9 & Conventional & 2016 & Triticale & $4^{\circ} 39^{\prime} 54^{\prime \prime} \mathrm{E}, 50^{\circ} 10^{\prime} 36^{\prime \prime} \mathrm{N}$; elev.: $190 \mathrm{~m}$ \\
\hline b10 & Organic & 2012 & Wheat & $4^{\circ} 38^{\prime} 04^{\prime \prime} \mathrm{E}, 50^{\circ} 06^{\prime} 07^{\prime \prime} \mathrm{N}$; elev.: $233 \mathrm{~m}$ \\
\hline b11 & Conventional & 2012 & Wheat & $5^{\circ} 12^{\prime} 19^{\prime \prime} \mathrm{E}, 50^{\circ} 04^{\prime} 46^{\prime \prime} \mathrm{N}$; elev.: $314 \mathrm{~m}$ \\
\hline b12 & Organic & 2007 & Wheat & $5^{\circ} 26^{\prime} 37^{\prime \prime} \mathrm{E}, 50^{\circ} 23^{\prime} 47^{\prime \prime} \mathrm{N}$; elev.: $292 \mathrm{~m}$ \\
\hline b13 & Organic & 2015 & Rye & $5^{\circ} 30^{\prime} 16^{\prime \prime} \mathrm{E}, 50^{\circ} 05^{\prime} 58^{\prime \prime} \mathrm{N}$; elev.: $413 \mathrm{~m}$ \\
\hline b14 & Organic & 2011 & Oat & $4^{\circ} 57^{\prime} 25^{\prime \prime} \mathrm{E}, 50^{\circ} 09^{\prime} 24^{\prime \prime} \mathrm{N}$; elev.: $270 \mathrm{~m}$ \\
\hline
\end{tabular}


- all plant species, Pielou's evenness ( $\mathrm{J}_{\text {tot }}$ ) (Pielou, 1966);

- segetal plant species, Pielou's evenness ( $\left.{ }^{\prime}{ }_{\text {seg }}\right)$.

All indices were computed at plot level, except for $\mathrm{J}_{\text {tot }}$ and $\mathrm{J}_{\text {seg }}$, which were computed at the margin level (aggregation of the 5 plots). Indeed, computation at the plot level for this index led to aberrant values for many plots, due to their low species richness.

Segetal status was established, based on the habitat descriptions in Lambinon et al. (2004), and by comparison with neighbouring countries' segetal species lists (Hofmeister \& Garve, 1998 for Germany; Cambecèdes et al., 2012 for France). Conservation status was taken from the Walloon red list for plant species (Saintenoy-Simon et al., 2006). Threatened species cover and richness were not considered for analysis, due to their too low values in most of the fields. Their occurrence is treated qualitatively in both the results and discussion sections. Pernicious weeds were discriminated according to Storkey \& Westbury (2007).

In order to test for difference in plot biodiversity indices between (i) AES and control, and (ii) conventional and organic farming, we performed linear mixed-effects models (LME). Variable $\mathrm{S}_{\text {tot }}$ was square root-transformed, and $\mathrm{S}_{\text {seg }}, \mathrm{Cov}_{\text {tot }}, \mathrm{Cov}_{\text {seg }}$ and $\mathrm{Cov}_{\text {pern }}$ were log-transformed, in order to improve their normality and homoscedasticity. Field was included as a random effect in our models. In doing so, we took into account the non-independence of 10 plots from the same study field. LME were realized using the R-package 'nlme' (Pinheiro et al., 2013). Model significances were tested with the ANOVA test. In the case of the AES*agriculture system interaction significance $(p<0.05)$, we tested for AES significance in each agricultural system separately.

In order to analyze variation between the AES and control margins, in organic and conventional study fields, two Principle Coordinate Analyses (PCoA) were applied at the margin level (5-plot mean cover values). The first PCoA was aimed at describing variations in species composition, based on Jaccard distances. The second was based on Bray-Curtis distance, with the aim of analyzing variations in species abundance. PCoA were realized using R-package 'vegan' (Oksanen et al., 2016).

\section{RESULTS}

A total of 67 species, including 11 segetal species (Table 2), were identified in the entire survey. In the organic and conventional agricultural systems, 56 species (9 segetal) and 44 species (7 segetal) were found, respectively. In organic agriculture, 49 species
(8 segetal) were found in the AES and 46 (7 segetal) in the control. In conventional agriculture, 42 species (7 segetal) were found in the AES and 22 (4 segetal) in the control. Only 3 (or 4, as we were unable to discriminate between Valerianella dentata and Valerianella rimosa) threatened species were found during our survey (Table 2). Of these, only Centaurea cyanus was found in rather large amounts in the organic fields. In the conventional fields, it was only found once in an AES margin, with low cover $(<1 \%)$. Other threatened species were found in low covers $(<1 \%)$, only in AES margins (Valerianella dentata/rimosa in two organic fields, Euphorbia platyphyllos in one conventional field).

Total species richness was higher in the AES margins than in the control, regardless of agriculture system $(p<0.01$; Table 3). Segetal species richness was only increased by the AES in the case of conventional fields $(p<0.001)$. Also, organic fields were species richer than conventional in both total and segetal species $(p<0.01$ and $p<0.05$, respectively). The impact of the AES on cover indices $\left(\mathrm{Cov}_{\text {tot }}, \mathrm{Cov}_{\text {seg }}\right.$ and $\mathrm{Cov}_{\text {pern }}$ ) differed between conventional and organic fields, as suggested by significant interactions between the AES and the agricultural system. In conventional fields, all cover indices, including segetal species and pernicious weeds, increased under the AES (Table 3). Conversely, in the organic fields, total and segetal species cover were not significantly affected by the AES, while pernicious weeds tended to decrease under the AES $(p>0.01)$. Alopecurus myosuroides was the most frequent and abundant pernicious weed in the conventional fields. In the organic fields, Lolium multiflorum was the most abundant, especially in the control margins (Table 2). Total evenness ( ${ }^{\prime}{ }_{\text {tot }}$ ) was higher in organic than in conventional fields.

Axes 1 and 2 of the PCoA based on species-cover data respectively explained $16.1 \%$ and $11.7 \%$ of the variance. This analysis revealed that vegetation changes were relatively substantial between AES margins and their respective controls in some fields (Figure 1). This was particularly the case in conventional and, to a lesser extent, in organic agriculture. In conventional agriculture, there was a general trend towards negative values on PCoA axis 1 under the AES. This principally corresponds to increased cover with the pernicious Alopecurus myosuroides and Bromus sterilis, but also the segetal Papaver rhoeas. In organic agriculture fields, no general trend could be discerned; however, several fields (b7, b8, b10, b13 and b14) had their AES margin toward positive values on both PCoA axes 1 and 2 (Figure 1). This region of the chart gathered fields with low total weed cover, therefore including conventional control margins. Two organic fields, however, had a clear inverse pattern (b5 and b6). Segregation between conventional and organic 
Table 2. Segetal and pernicious species found in survey (with Walloon red-list status: $C R=$ critically endangered, $\mathrm{VU}=$ vulnerable, $\mathrm{LC}=$ least concerned), percentage of margins where they occurred, and mean cover when they were present - Plantes messicoles et nuisibles trouvées dans les relevés (avec leur statut dans la liste rouge wallonne $: C R=$ en danger critique, $V U=$ vulnérable, $L C=$ préoccupation mineure), pourcentage de bande où elles sont présentes et abondance moyenne en cas de présence.

\begin{tabular}{|c|c|c|c|c|c|c|c|c|}
\hline \multirow[t]{3}{*}{ Species } & \multicolumn{4}{|c|}{ Conventional agriculture } & \multicolumn{4}{|c|}{ Organic agriculturel } \\
\hline & \multicolumn{2}{|c|}{ \%Margins } & \multicolumn{2}{|c|}{ Mean cover $(\%)$} & \multicolumn{2}{|c|}{ \%Margins } & \multicolumn{2}{|c|}{ Mean cover $(\%)$} \\
\hline & AES & Control & AES & Control & AES & Control & AES & Control \\
\hline \multicolumn{9}{|l|}{ Segetal species } \\
\hline Centaurea cyanus $(\mathrm{VU})$ & 16.7 & 0 & 0.7 & - & 62.5 & 37.5 & 21.9 & 46.8 \\
\hline Euphorbia platyphyllos (CR) & 16.7 & 0 & 0.1 & - & 0 & 0 & - & - \\
\hline Valerianella dentata/rimosa $(\mathrm{VU} / \mathrm{CR})$ & 0 & 0 & - & - & 25 & 0 & 0.2 & - \\
\hline Anagalis arvensis subsp. arvensis (LC) & 16.7 & 16.7 & 0.4 & 0.4 & 0 & 0 & - & - \\
\hline Anthemis arvensis (LC) & 0 & 0 & - & - & 0 & 12.5 & - & 0.1 \\
\hline Aphanes arvensis (LC) & 16.7 & 16.7 & 0.5 & 0.4 & 62.5 & 37.5 & 1 & 24.8 \\
\hline Fumaria officinalis (LC) & 0 & 0 & - & - & 12.5 & 12.5 & 0.2 & 8.2 \\
\hline Papaver rhoeas (LC) & 66.7 & 16.7 & 11 & 0.1 & 75 & 62.5 & 7.6 & 2.3 \\
\hline Sherardia arvensis (LC) & 0 & 0 & - & - & 12.5 & 0 & 0.1 & - \\
\hline Valerianella locusta (LC) & 16.7 & 0 & 4.8 & - & 12.5 & 12.5 & 3 & 16.5 \\
\hline Viola arvensis (LC) & 50 & 33.3 & 0.2 & 4 & 75 & 75 & 2.1 & 3 \\
\hline \multicolumn{9}{|l|}{ Pernicious species } \\
\hline Alopecurus myosuroides & 83.3 & 33.3 & 37.3 & 8.1 & 50 & 25 & 7.9 & 5.7 \\
\hline Avena fatua & 16.7 & 0 & 8.9 & - & 12.5 & 12.5 & 0.3 & 0.1 \\
\hline Bromus sterilis & 33.3 & 0 & 0.1 & - & 0 & 0 & - & - \\
\hline Cirsium vulgare & 16.7 & 0 & 0.1 & - & 12.5 & 0 & 0.1 & - \\
\hline Elymus repens & 0 & 0 & - & - & 0 & 12.5 & - & 0.2 \\
\hline Galium aparine & 33.3 & 33.3 & 0.3 & 0.1 & 75 & 25 & 0.3 & 0.8 \\
\hline Lolium multiflorum & 0 & 0 & - & - & 50 & 50 & 12.5 & 26.5 \\
\hline Rumex crispus & 33.3 & 0 & 0.3 & - & 37.5 & 37.5 & 0.7 & 5.0 \\
\hline Rumex obtusifolius & 50 & 16.7 & 0.5 & 0.3 & 50 & 37.5 & 0.4 & 0.2 \\
\hline
\end{tabular}

$\mathrm{AES}=$ agro-environmental scheme - mesure agro-environnementale.

fields was mainly found in PCoA, based on species composition (variance explained: $18.5 \%$ and $11.5 \%$ respectively for axes 1 and 2, Figure 2), where organic fields were mostly characterized by higher values on PCoA axis 1. Under the AES, most conventional fields tended to approach, or to reach, organic field coordinates.

\section{DISCUSSION}

\subsection{Strong effect of the AES in conventional fields}

The AES led to a rapid increase in weed diversity and cover in conventional fields. Regarding cover, this result was in part due to increased cover of only two species, i.e. A. mysosuroides and P. rhoeas. Both species were found in AES margins and in control margins. Both $A$. myosuroides and $P$. rhoeas are known to be herbicide resistant (Chauvel et al., 2009; Maréchal \& Henriet, 2012). This is congruent with Richner et al. (2015), who found that conventional management selects herbicideresistant plants. Alopecurus myosuroides is clearly seen as an undesirable and pernicious weed species that may discourage farmers to pursue their AES engagement over the 5-year term. Conversely, P. rhoeas is a segetal species that is rather well appreciated by farmers due to its aesthetic value, and is a good resource for pollinators (Frank, 1999; Hicks et al., 2016). Papaver rhoeas is known for its long-lasting seeds in soil seed 
a

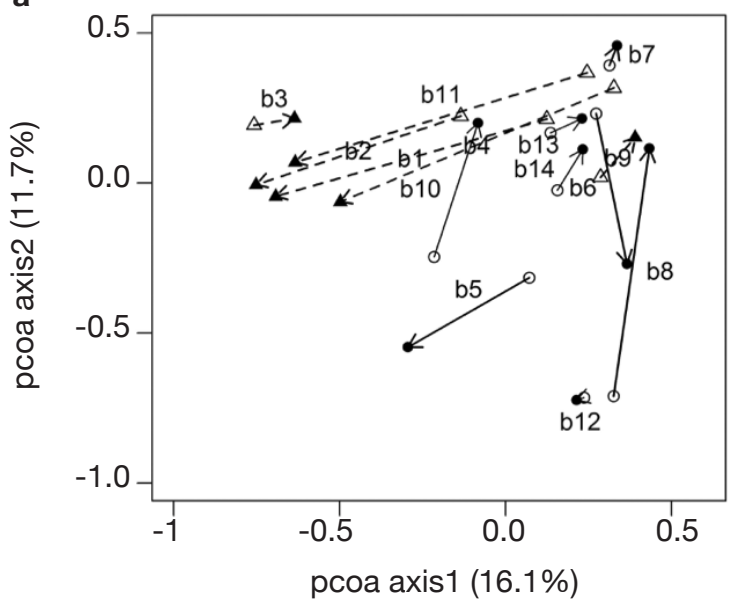

b

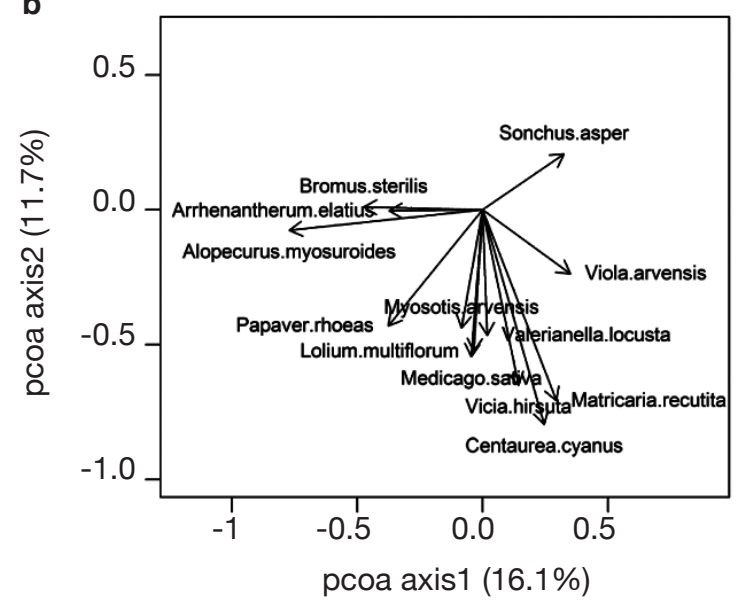

Figure 1. a. PCoA of the 14 margin pairs investigated (labels are field number, see Table 1), based on species cover data (Bray-Curtis distance was used). Circles: organic agriculture, triangles: conventional agriculture, full symbols: AES, empty symbols: control. Arrows link AES and control margins from the same field $-P c o A$ des 14 paires de bordures (les étiquettes correspondent aux numéros de champs, voir Table 1), sur base des abondances des espèces (les distances de Bray-Curtis ont été utilisées). Cercles : agriculture biologique, triangles : agriculture conventionnelle, symboles pleins : MAE, symboles vides: témoins. Les flèches relient les bordures MAE et témoins d'un même champ. b. Species projection in the same plane (only species having correlation with PCoA plane $>0.35$ are displayed) - Projection des espèces dans le même plan (seules les espèces dont la corrélation avec le plan $>0,35$ sont affichées).

banks, and its high seed production (Baskin et al., 2002; Torra \& Recasens, 2008). These characteristics may be advantageous for a rapid spread under AES management. An AES in conventional fields can therefore provide a rapid response in the short term, but the first species that recolonize under an AES are likely already present in the field, or in nearby surroundings 


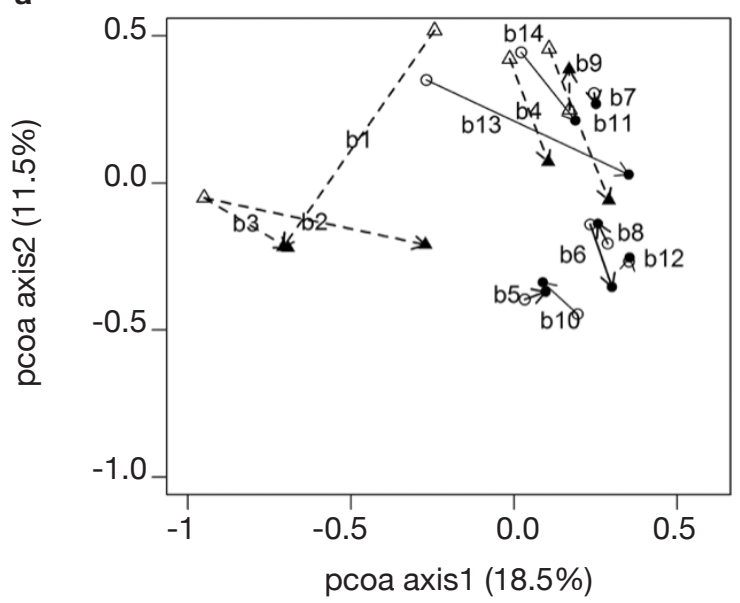

b

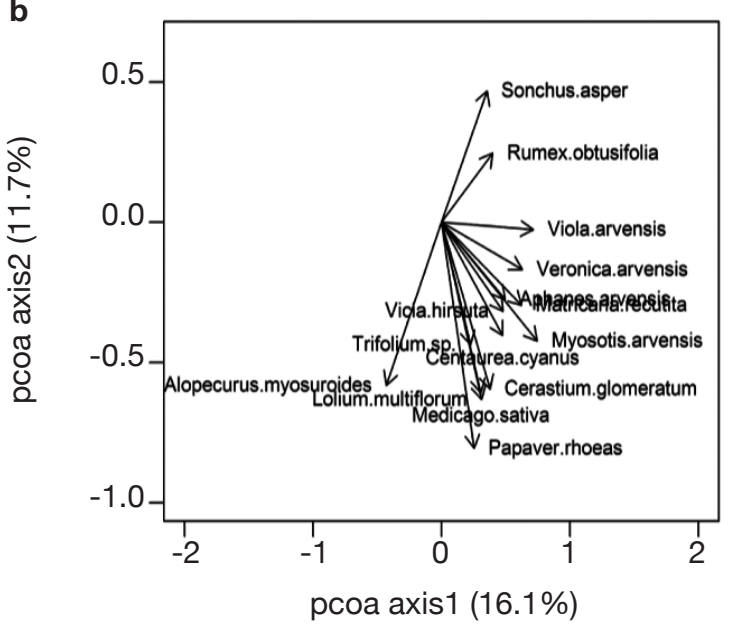

Figure 2. a. PCoA of the 14 margin pairs investigated (labels are field number, see Table 1), based on species occurrence data (Jaccard distance was used). Circles: organic agriculture, triangles: conventional agriculture, full symbols: AES, empty symbols: control. Arrows link AES and control margins from the same field - PcoA des 14 paires de bordures (les étiquettes correspondent aux numéros de champs, voir Table 1), sur base des présences des espèces (les distances de Jaccard ont été utilisées). Cercles : agriculture biologique, triangles : agriculture conventionnelle, symboles pleins : MAE, symboles vides : témoins. Les flèches relient les bordures MAE et témoins d'un même champ. b. Species projection in the same plane (only species having correlation with PCoA plane $>0.35$ are displayed) - Projection des espèces dans le même plan ( seules les espèces dont la corrélation avec le plan $>0,35$ sont affichées).

(Kleijn \& Van Der Voort, 1997; Gerbaud et al., 1999). An AES would be most successful if it could control development of the pernicious A.myosuroides. This species has an early germination. Delayed sowing of winter cereals may therefore help at controlling it
(Lutman et al., 2013). It may also be limited through the introduction of spring crops into the crop rotation (Chauvel et al., 2001) or through sowing non-crop plant species (van Elsen \& Hotze, 2008; Pywell et al., 2011).

\subsection{Positive effect of organic agriculture, further improved by the AES}

Organic fields were found to be more diverse than conventional ones. This is congruent with most studies on that subject, although some counter-examples exist (see Albrecht et al., 2016 for a synthesis). Indeed, for most diversity variables, control margins in organic agriculture are similar to those in AES in conventional agriculture; however, PCoA demonstrates that vegetation is different between these two farming systems. While A.myosuroides and P.rhoeas dominated in conventional AES fields, organic fields were generally co-dominated by several species, which explains their higher evenness $\left(\mathrm{J}^{\prime}{ }_{\text {tot }}\right)$. Despite the higher reference level, the AES proved to enhance species richness $\left(\mathrm{S}_{\text {tot }}\right)$ in organic fields, although to a lesser extent than in conventional fields. Interestingly, organic AES fields also contributed to a decrease in pernicious weeds. Even if the total cover decrease was not significant in the organic AES, such a trend was observed in several fields, according to the PCoA results. Fields having an inverse trend were, as a matter of fact, converted to organic agriculture less than two years ago. It is worth noting that the absence of abundant species in these cases makes them artificially approach conventional control margins in cover-based PCoA (Figure 1); however presence-based PCoA (Figure 2) revealed that they were clearly different, in terms of species composition and richness. Hence, AES management, including absence of fertilization, may lead to a thinning of vegetation that could decrease uptake of light by dominant plants, especially the pernicious ones. This may, therefore, diminish their competition abilities (Davis et al., 2000; Gibson et al., 2012), and allow easier establishment of new species. This is in accordance with previous studies that have claimed the benefits of lower fertilization rates for segetal plants, due to competition decrease (Kleijn \& Van Der Voort, 1997; Rotchés-Ribalta et al., 2016). Given the amount of the subsidies $\left(1,250 € \cdot \mathrm{ha}^{-1} \cdot\right.$ year $^{-1}$ for the AES, or $400 € \cdot \mathrm{ha}^{-1}$.year ${ }^{-1}$ for organic agriculture, not combinable with each other), one can argue that an AES has a lower cost-efficiency than organic agriculture; however, study fields are located where the arable plant species pool is still rich, according to one targeting criterion for AES implementation (at least one threatened segetal species observed after 2010 within a $500 \mathrm{~m}$ radius). Organic fields included in our survey 
are, therefore, unlikely to be representative of all fields in Wallonia, as local species pools have proved to have a major impact on species composition in arable fields (Rotchés-Ribalta et al., 2015). This targeting is likely to improve the efficiency of AES, as less area has to be included to achieve conservation aims. Further, the presence of the AES likely influenced the results in the control, especially in organic fields. Indeed, to facilitate field management, most farmers (all except one in this study) applied the AES's rotation constraint (cereals at least 3 years over the 5-year contract) in the entire field, including the control margin. It is likely that, if not committed to an AES, farmers would have increased grass-clover crop frequency into crop rotation, which is frequently used in organic agriculture, notably to reduce weed pressure (Albrecht, 2005). This practice is however likely to have detrimental effects on threatened species too (Albrecht et al., 2016). Increased cereal frequencies in the rotations therefore likely led to enhanced performance of the control margins in organic fields, in terms of segetal plant conservation.

\subsection{Conservation of threatened species}

Only 3 or 4 (V. dentata and V. rimosa could not be distinguished) rare or threatened species were found in our survey. Except for C. cyanus in organic fields, these were only found in AES margins; however, a separate monitoring involving the compilation of full species lists of AES margins conducted at 12 of our 14 study sites during the same year (2016) yielded up to 5 threatened segetal species at each site (mean 2.8 species/site) and a total of 13 threatened species, including the 4 we found in this study (Natagriwal, unpublished data). These species were mainly found at the edges of the fields (first sowing lines or field corners), known to be lesser impacted by farming practices than field interiors, due to inaccurate herbicide application and mechanical constrains (Fried et al., 2008). This observation proves that these species were unable to recolonize the 6 first meters of the inner field, within a couple of years, under the AES. It may be due to their mainly barochoric dispersal (Affre et al., 2003). Before the industrialization of agriculture, these species were dispersed with uncleaned seeds. Nowadays, human-induced dispersal is mainly a result of manure application, and soil adhering to materials during cultivation works (Mayer \& Albrecht, 2008); however, rare and threatened segetal plants have a lower probability to be dispersed that way, because of low population densities. Indeed, remaining rare species rarely form populations larger than tens of individuals at each study site (J. Piqueray, pers. obs.). Therefore they are unlikely to be detected through a vegetation plot survey, like the one reported in this paper. For rare species, demographic studies are therefore needed to assess population size tendencies and inner-field colonization.

\section{CONCLUSIONS}

Although the AES in Wallonia proved generally efficient for arable plant conservation, it failed in most of the cases at restoring huge populations of threatened species, despite their occurrence in field edges. In order to restore the dispersal abilities of segetal species, several techniques could be considered, notably the sowing of threatened species. This proves efficient in many cases (Albrecht et al., 2016; Lang et al., 2016); however, it requires overcoming the problem of seed sourcing, and assisting famers in operations. Conversely, sowing uncleaned seed from fields with a well-preserved segetal flora could be an interesting option, easily feasible with farming machinery. This was indeed one of the historical ways of dispersal for segetal species, that was disrupted due to agricultural modernization (Albrecht et al., 2016). Species introduction may limit the risks of invasion by undesirable species, improve aesthetic value, provide ecological benefits, and improve segetal species dissemination between and within fields (Albrecht et al., 2016). In order to improve farmer acceptance, harrowing could be allowed in an AES to control unfavorable weeds. This technique is known to decrease weed cover, while preserving arable weed richness (Rasmussen, 2004; Armengot et al., 2013).

\section{Acknowledgements}

The authors acknowledge the farmers who participated in this study. Natagriwal is a non-for-profit association funded by the Walloon government.

\section{Bibliography}

Affre L., Dutoit T., Jagër M. \& Garraud L., 2003. Écologie de la reproduction et de la dispersion, et structure génétique chez les espèces messicoles : propositions de gestion dans le Parc naturel régional du Luberon. Actes $B R G, \mathbf{4}, 405-428$.

Albrecht H., 2005. Development of arable weed seedbanks during the 6 years after the change from conventional to organic farming. Weed Res., 45(5), 339-350.

Albrecht H., Cambecèdes J., Lang M. \& Wagner M., 2016. Management options for the conservation of rare arable plants in Europe. Bot. Lett., 8107(November), 1-27.

Armengot L., José-María L., Chamorro L. \& Sans F.X., 2013. Weed harrowing in organically grown cereal crops avoids yield losses without reducing weed diversity. Agron. Sustain. Dev., 33(2), 405-411. 
Baskin C.C., Milberg P., Andersson L. \& Baskin J.M., 2002. Non-deep simple morphophysiological dormancy in seeds of the weedy facultative winter annual Papaver rhoeas. Weed Res., 42(3), 194-202.

Batáry P., Dicks L.V., Kleijn D. \& Sutherland W.J., 2015. The role of agri-environment schemes in conservation and environmental management. Conserv. Biol., 29(4), 1006-1016.

Bengtsson J.,Ahnström J. \& Weibull A.C., 2005. The effects of organic agriculture on biodiversity and abundance: a meta-analysis. J. Appl. Ecol., 42(2), 261-269.

Bock L. et al., 2008. Carte Numérique des Sols de Wallonie - version 1.2. Convention financée par la Région Wallonne (DGA, MRW), Unité Sol-ÉcologieTerritoire (Laboratoire de Géopédologie) et Unité de Gestion des Ressources forestières et des Milieux naturels. Gembloux, Belgique : Faculté universitaire des Sciences agronomiques de Gembloux.

Braun-Blanquet J., 1932. Plant sociology: the study of plant communities. New York, NY, USA: McGraw-Hill Book Company, Inc.

Cambecèdes J., Largier G. \& Lombard A., 2012. Plan national d'actions en faveur des plantes messicoles 2012 2017. Bagnères-de-Bigorre, France: Conservatoire botanique national des Pyrénées et de Midi-Pyrénées ; Montreuil-sous-Bois, France : Fédération des Conservatoires botaniques nationaux ; Paris : Ministère de l'Écologie, du Développement durable et de l'Énergie.

Chauvel B., Guillemin J.P., Colbach N. \& Gasquez J., 2001. Evaluation of cropping systems for management of herbicide-resistant populations of blackgrass (Alopecurus myosuroides Huds.). Crop Prot., 20(2), 127-137.

Chauvel B., Guillemin J.P. \& Colbach N., 2009. Evolution of a herbicide-resistant population of Alopecurus myosuroides Huds. in a long-term cropping system experiment. Crop Prot., 28(4), 343-349.

Davis M.A., Grime J.P. \& Thompson K., 2000. Fluctuating resources in plant communities: a general theory of invasibility. J. Ecol., 88(3), 528-534.

Frank T., 1999. Density of adult hoverflies (Dipt., Syrphidae) in sown weed strips and adjacent fields. J. Appl. Entomol., 123(6), 351-355.

Fried G., Norton L.R. \& Reboud X., 2008. Environmental and management factors determining weed species composition and diversity in France. Agric. Ecosyst. Environ., 128(1-2), 68-76.

Fried G., Petit S., Dessaint F. \& Reboud X., 2009. Arable weed decline in Northern France: crop edges as refugia for weed conservation? Biol. Conserv., 142(1), 238-243.

Gerbaud E., Dutoit T.\& Hill B., 1999. Étude de la répartition des plantes messicoles dans un champ en liaison avec une mesure agri-environnementale. Courr. Sci. Parc Nat. Régional Lubéron, 3, 88-101.

Gibson D.J., Allstadt A.J., Baer S.G. \& Geisler M., 2012. Effects of foundation species genotypic diversity on subordinate species richness in an assembling community. Oikos, 121(4), 496-507.

Haaland C., Naisbit R.E. \& Bersier L.F., 2011. Sown wildflower strips for insect conservation: a review. Insect Conserv. Divers., 4(1), 60-80.

Hicks D.M. et al., 2016. Food for pollinators: quantifying the nectar and pollen resources of urban flower meadows. PLoS One, 11(6), e0158117.

Hofmeister H. \& Garve E., 1998. Lebensraum Acker. Berlin, Deutschland: Parey Buch Verlag.

Hyvönen T. et al., 2003. Weed species diversity and community composition in organic and conventional cropping of spring cereals. Agric. Ecosyst. Environ., 97(1-3), 131-149.

Kleijn D. \& Van Der Voort L.A.C., 1997. Conservation headlands for rare arable weeds: the effects of fertilizer application and light penetration on plant growth. Biol. Conserv., 81(1-2), 57-67.

Lambinon J., Delvosalle L.\& Duvigneaud J.,2004. Nouvelle flore de Belgique, du Grand-Duché de Luxembourg, du Nord de la France et des régions voisines. Meise, Belgique : Jardin botanique national de Belgique.

Lang M. et al., 2016. Reintroduction of rare arable plants by seed transfer. What are the optimal sowing rates? Ecol. Evol., 6(15), 5506-5516.

Lutman P.J.W., Moss S.R., Cook S. \& Welham S.J., 2013. A review of the effects of crop agronomy on the management of Alopecurus myosuroides. Weed Res., 53(5), 299-313.

Maréchal P. \& Henriet F., 2012. Ecological review of blackgrass (Alopecurus myosuroides Huds.) propagation abilities in relationship with herbicide resistance. Biotechnol. Agron. Soc. Environ., 16(1), 103-113.

Marshall E.J.P. et al., 2003. The role of weeds in supporting biological diversity within crop fields. Weed Res., 43(2), 77-89.

Mayer F. \& Albrecht H., 2008. Dispersal strategies. Are they responsible for species success in arable ecosystems? In: Schröder P., Pfadenhauer J. \& Muench J.C., eds. Perspectives for agroecosystem management: balancing environmental and socio-economic demands., Amsterdam, The Netherlands; Oxford, UK: Elsevier, 257-278.

Nicholls C. \& Altieri M., 2004. Designing species-rich, pest-suppressive agroecosystems through habitat management. Agronomy, 43, 49-62.

Nicholls C.I. \& Altieri M.A., 2013. Plant biodiversity enhances bees and other insect pollinators in agroecosystems. A review. Agron. Sustain. Dev., 33(2), 257-274.

Oksanen A.J. et al., 2016. Package "vegan” (Version 2.4-0), https//cran.r-project.org, https//github.com/vegandevs/ vegan, (08/12/2017).

Pielou E.C., 1966. The measurement of diversity in different types of biological collections. J. Theor. Biol., 13, 131144. 
Pinheiro J., Bates D., DebRoy S. \& Sarkar D., 2013. NLME: linear and nonlinear mixed effects models. $R$ Packag. version 3.1-122, http//CRAN.R-project.org/ package $=$ nlme Version 3., 1-336, (08/12/2017).

Piqueray J., Rouxhet S., Hendrickx S. \& Mahy G., 2016. Changes in the vegetation of hay meadows under an agri-environment scheme in South Belgium. Conserv. Evidence, 13, 47-50.

Pywell R.F. et al., 2011. Ecological restoration on farmland can drive beneficial functional responses in plant and invertebrate communities. Agric. Ecosyst. Environ., 140(1-2), 62-67.

Rasmussen I.A., 2004. The effect of sowing date, stale seedbed, row width and mechanical weed control on weeds and yields of organic winter wheat. Weed Res., 44(1), 12-20.

Richner N., Holderegger R., Linder H.P. \& Walter T., 2015. Reviewing change in the arable flora of Europe: a metaanalysis. Weed Res., 55(1), 1-13.

Rotchés-Ribalta R. et al., 2015. Which conditions determine the presence of rare weeds in arable fields? Agric. Ecosyst. Environ., 203, 55-61.

Rotchés-Ribalta R., Blanco-Moreno J.M., Armengot L. \& Sans F.X., 2016. Responses of rare and common segetal species to wheat competition and fertiliser type and dose. Weed Res., 56(2), 114-123.

Saintenoy-Simon J. et al., 2006. Première liste des espèces rares, menacées et protégées de la Région Wallonne (Ptéridophytes et Spermatophytes), http://biodiversite.wallonie.be/fr/liste-des-taxons . html?IDD=1755\&IDC=3076, (08/12/2017).

Service public de Wallonie, 2017a. Mesure 10 : paiements agroenvironnementaux, https://agriculture.wallonie. be/documents/20182/21864/PWDR-19.pdf/7497be9d2372-46e7-871d-ff69ef61b52a, (05/12/2017).
Service public de Wallonie, 2017b. Mesure 11 : paiements en faveur de l'agriculture biologique, https://agriculture. wallonie.be/documents/20182/21864/PWDR-20. pdf/9b91be 5 b- 1 bfc-4b45-bc6a-c7249a5552f6, $(05 / 12 / 2017)$.

Stoate C. et al., 2001. Ecological impacts of arable intensification in Europe. J. Environ. Manage., 63(4), 337-365.

Storkey J. \& Westbury D.B., 2007. Managing arable weeds for biodiversity. Pest Manage. Sci., 63(6), 517-523.

Storkey J., Meyer S., Still K.S. \& Leuschner C., 2012. The impact of agricultural intensification and land-use change on the European arable flora. Proc. R. Soc. London, Ser. $B, 279$ (1732), 1421-1429.

Sutcliffe L.M.E. et al., 2015. Harnessing the biodiversity value of Central and Eastern European farmland. Divers. Distrib., 21(6), 722-730.

Torra J. \& Recasens J., 2008. Demography of corn poppy (Papaver rhoeas) in relation to emergence time and crop competition. Weed Sci., 56(6), 826-833.

Tscharntke T. et al., 2005. Landscape perspectives on agricultural intensification and biodiversity - Ecosystem service management. Ecol. Lett., 8(8), 857-874.

van Elsen T.\& Hotze C., 2008. The integration of autochthon arable field plants and the corncockle into flower strips for organic farming. J. Plant Dis. Prot., 21, 373-377.

Wagner M. et al., 2017. Cereal density and N-fertiliser effects on the flora and biodiversity value of arable headlands. Biodivers. Conserv., 26(1), 85-102.

Wilson J.D. et al., 1999. A review of the abundance and diversity of invertebrate and plant foods of granivorous birds in northern Europe in relation to agricultural change. Agric. Ecosyst. Environ., 75(1-2), 13-30.

(52 ref.) 